\title{
PENGARUH KARAKTERISTIK PEMERINTAH DAERAH TERHADAP KINERJA PEMERINTAH DAERAH (STUDI PADA PEMERINTAH KABUPATEN/KOTA DI PROVINSI JAMBI)
}

\author{
Lia Anggraini ${ }^{1)}$, Sri Rahayu ${ }^{2),}$ Junaidi $^{3)}$ \\ 1) Alumni Magister Ilmu Akuntansi Pascasarjana Universitas Jambi Tahun 2019 \\ ${ }^{2 \& 3)}$ Dosen Pembimbing
}

\begin{abstract}
The purpose of this study is to provide empirical evidence of the influence of the characteristics of local governments on the performance of municipal / regency regional governments in Jambi Province. The population in this study were 11 districts / cities (9 districts and 2 cities) in Jambi Province in 2011-2015, the number of observations in this study was 55. The analytical method used was quantitative analysis, with panel data regression models using Eviews.10. The results of the study show: (1) The size of the local government does not affect the performance of the district / city government in Jambi Province. (2) The level of regional wealth has an effect on the performance of the district / city local government in Jambi Province. (3) Dependence on the Center has an effect on the performance of the district / city government in Jambi Province, (4) Capital expenditure Ratio does not affect the performance of the regency and city governments in Jambi Province, (5) Legislative Size does not affect the performance of district / city governments in Jambi Province, (6) Leverage does not affect the performance of district / city governments in Jambi Province (7) Size of regional government, level of regional wealth, dependence on the center, capital expenditure, legislative size, and leverage on Government performance Regency / City Region in Jambi Province.
\end{abstract}

Keywords: Local Government Size, Regional Wealth Level, Dependence on Center, Capital Expenditures, Legislative Size, Leverge.

\begin{abstract}
ABSTRAK
Penelitian bertujuan untuk memberikan bukti empiris pengaruh Karakteristik Pemerintah Daerah terhadap Kinerja Pemerintah Daerah kota/kabupaten di Provinsi Jambi. Populasi dalam penelitian ini adalah 11 kabupaten/kota (9 kabupaten dan 2 kota) pada Provinsi Jambi Tahun 2011-2015, jumlah pengamatan penelitian ini sebanyak 55. Metode analisis yang digunakan adalah analisis kuantitatif, dengan model regresi data panel dengan menggunakan Eviews. 10. Hasil penelitian menunjukkan: (1) Ukuran pemerintah daerah tidak berpengaruh terhadap kinerja pemerintah daerah Kabupaten/Kota di Provinsi Jambi. (2) Tingkat kekayaan daerah berpengaruh terhadap kinerja pemerintah daerah Kabupaten/Kota di Provinsi Jambi. (3) Ketergantungan pada Pusat berpengaruh terhadap kinerja pemerintah daerah Kabupaten/Kota di Provinsi Jambi, (4) Rasio belanja modal tidak berpengaruh terhadap kinerja pemerintah daerah kabupaten dan kota di Provinsi Jambi, (5) Ukuran Legislatif tidak berpengaruh terhadap kinerja pemerintah daerah kabupaten/kota di Provinsi Jambi, (6) Leverage tidak berpengaruh terhadap kinerja pemerintah daerah Kabupaten/Kota di Provinsi Jambi.(7) Ukuran pemerintah daerah, tingkat kekayaan daerah, ketergantungan pada pusat ,belanja modal, ukuran legislative, dan Leverage berpengaruh terhadap kinerja Pemerintah Daerah Kabupaten/Kota di Provinsi Jambi.
\end{abstract}

Kata Kunci: Ukuran Pemerintah Daerah, Tingkat Kekayaan Daerah, Ketergantungan pada Pusat, Rasio Belanja Modal, Ukuran Legislatif, Leverge. 


\section{PENDAhuluan 1.1. Latar Belakang}

Undang-Undang Nomor 23 tahun 2014 tentang Pemerintah Daerah melahirkan paradigma baru dalam pelaksanaan otonomi daerah, yang meletakkan otonomi penuh, luas, dan bertanggung jawab pada daerah. Dengan berjalannya otonomi daerah dilingkungan pemerintah daerah, Pemerintah Daerah dituntut memberikan laporan pertanggungjawaban atas penyelenggaraan pemerintah daerah kepada masyarakat yaitu Laporan Penyelenggaraan Pemerintah Daerah (LPPD) yang di berikan kepada Pemerintah Pusat. Terselenggaranya Laporan Penyelenggaraan Pemerintah Daerah (LPPD) dari Pemerintah Daerah, maka perlunya pengawasan dan evaluasi dari pengukuran kinerja Pemerintah Daerah agar terciptanya karakteristik pemerintahan yang akuntabilitas dan transparansi dalam penyelenggaraan otonomi daerah berkesinambungan Laporan Penyelenggaraan Pemerintah Daerah (LPPD) dengan kinerja pemerintah daerah tersebut (UU No.23/2014).

Undang-Undang No. 23 Tahun 2014 Pemberian otonomi yang luas dan bertanggungjawab kepada Kabupaten dan Kota memberikan jalan bagi pemerintah daerah untuk melakukan pembaharuan dalam sistem pengelolaan keuangan daerah. Pemerintah daerah dituntut untuk dapat mengelolola keuangan daerah secara baik dalam bentuk penyelenggaraan program dan kegiatan yang tertuang dalam Anggaran Pendapatan dan Belanja Daerah (APBD) yang disusun secara mandiri oleh Pemda dan menjadi dasar dalam penyelenggaraan pemerintah di wilayahnya masingmasing. Peraturan Pemerintah (PP) Nomor 71 Tahun 2010 tentang Standar Akuntansi Pemerintahan menyebutkan bahwa adanya Laporan Keuangan Pemerintah Daerah (LKPD) dapat dibandingkan untuk melihat kinerja keuangan dengan anggaran, menilai kondisi dan hasil operasional, membantu menentukan tingkat kepatuhan terhadap peraturan perundangan yang terkait dengan masalah keuangan dan ketentuan lainnya serta membantu mengevaluasi tingkat efisiensi dan efektivitas kinerja Pemda.

UU No. 23/2014 memberikan kewenangan otonomi kepada Pemda juga mewajibkan tiap kepala daerah untuk memberikan Laporan Penyelenggaraan Pemerintah Daerah (LPPD) kepada pemerintah pusat. Pasal 2 Peraturan Pemerintah Nomor 3 tahun 2007 (PP No.3/2007) tentang laporan penyelenggaraan pemerintahan daerah kepada pemerintah, laporan keterangan pertanggungjawaban kepala daerah kepada dewan perwakilan rakyat daerah, dan informasi laporan penyelenggaraan pemerintahan daerah kepada masyarakat menyebutkan bahwa ruang lingkup LPPD mencakup penyelenggaraan urusan desentralisasi, tugas pembantuan dan tugas umum pemerintahan. Penyelenggaraan urusan desentralisasi meliputi urusan wajib dan pilihan. Urusan wajib adalah urusan yang sangat mendasar yang berkaitan dengan hak dan pelayanan dasar warga negara. Sedangkan urusan pilihan merupakan urusan yang secara nyata ada di daerah dan berpotensi untuk meningkatkan kesejahteraan masyarakat, sesuai dengan kondisi, kekhasan dan potensi unggulan daerah. Dengan demikian, isi dari Laporan Penyelenggaraan Pemerintah Daerah (LPPD) Pemda kabupaten/kota sangat tergantung dengan urusan yang menjadi tanggung jawabnya dan karakteristik dari masing-masing Pemda tersebut (Mustikarini, 2012).

Laporan Penyelenggaraan Pemerintah Daerah (LPPD) yang telah dibuat oleh Pemda di evaluasi oleh Pemerintah Pusat dalam bentuk Evaluasi Kinerja Penyelenggaraan Pemerintah Daerah (EKPPD), dimana pedoman ini diatur berdasarkan Peraturan Pemerintah (PP) Nomor 6 Tahun 2008 tentang Pedoman Evaluasi Penyelenggaraan Pemerintahan Daerah. EKPPD digunakan oleh Pemerintah Pusat sebagai bahan acuan untuk menilai kinerja setiap Pemda. EKPPD merupakan evaluasi kinerja Pemda dalam bentuk skor secara nasional dengan menggunakan Indikator Kinerja Kunci (IKK). Tata cara pelaksanaan EKPPD diatur lebih lanjut dalam Peraturan Menteri Dalam Negeri Nomor 73 Tahun 2009 (Permendagri No.73/2009), dimana pada Pasal 5 Permendagri No.73/2009 dijelaskan bahwa EKPPD menggunakan LPPD sebagai sumber informasi utama yang difokuskan pada informasi pencapaian kinerja pada tataran pengambilan kebijakan dan pelaksanaan kebijakan dengan menggunakan Indikator Kinerja Kunci (IKK). Peringkat hasil EKPPD secara nasional menggunakan template analisis indeks dengan hasil akhir berupa "Indeks Hasil Evaluasi LPPD" yang selanjutnya disebut sebagai skor kinerja. Kriteria penilaian yang ditetapkan terhadap skor kinerja dibagi kedalam empat tingkatkan prestasi yaitu Prestasi Sangat Tinggi (ST), Prestasi Tinggi (T), Prestasi Sedang (S) dan Prestasi Rendah (R). (Rini, 2015).

EKPPD Pelaksanaan pertama dan kedua merupakan tahap uji coba atau simulasi dilakukan pada tahun 2009, pada tahun 2015 untuk pelaksanaan ketujuh yaitu EKPPD terhadap LPPD Tahun 2015 dilaksanakan bulan desember 2016, dan hasil EKPPD yang digunakan data terbaru yang sudah dipublikasi, sehingga data yang dapat diperoleh oleh peneliti adalah hasil EKPPD untuk tahun 2011-2015.

Kinerja Pemerintah Daerah dapat dihubungkan dengan karakteristik Pemerintah Daerah, menurut Penelitian Patrick (2007) menggunakan proksi karakteristik pemerintah daerah berupa budaya organisasi, struktur organisasi (ukuran pemerintah), dan 
lingkungan eksternal (kewajiban dan pendapatan pemerintah daerah) terhadap standar akuntansi pemerintah (Governmental Accounting Standard Board 34), menurut Patrick (2007) Rendahnya kepatuhan dari pemerintah lokal pennsylvania berdasarkan GASB 34, hal ini perlunya tindak lanjut dalam perubahan penerapan kepatuhan GASB 34. Perlunya Laporan keuangan pemerintah daerah pennsylvania berdasarkan GAAP, dan mengadopsi GASB 34, hal tersebut sebagai syarat dalam perjanjian utang, mendapatkan penghargaan atas laporan keuangannya, menerima hibah dan pendanaan dari pemerintah pusat, namun laporan pemerintah daerah yang tidak sesuai dengan GAAP mereka cenderung kurang kapasitas administratif dan kewajiban yang mereka miliki.

Kriteria Prestasi Skor EKPPD Kabupaten/Kota di Provinsi Jambi tahun 2011-2015 ditemukan bahwa secara umum skor kinerja penyelenggaraan pemerintah daerah di Provinsi Jambi dari Tahun 2011 hingga 2015 mengalami ketidakstabilan skor kinerja dari hasil EKPPD, pada tahun 2012 terdapat 7 Kabupaten di Provinsi Jambi mengalami penurunan skor kinerja, yaitu Kabupaten Muaro Jambi, Kabupaten Sarolangun, Kabupaten Merangin, Kabupaten Tebo, Kabupaten Tanjung Jabung Barat, dan Kabupaten Kerinci dengan range indeks EKPPD Sedang (S), namun tahun 2015 pada 7 Kabupaten yang mengalami peningkatan yang pesat dari range indeks EKPPD Sedang (S) menjadi Range Indeks EKPPD Tinggi (T) maupun Sangat Tinggi (ST). Faktor-faktor yang mempengaruhi kinerja Pemerintah Daerah menurut Patrick (2007) adalah pengaruhnya budaya organisasi, struktur organisasi (ukuran organisasi meliputi pendapatan organisasi), dan lingkungan eksternal (Kewajiban yang dimiliki organisasi). Penelitian tentang kinerja Pemerintah Daerah yang dilakukan oleh Siti (2016) menyatakan bahwa faktor yang mempengaruhi kinerja pemda meliputi aset yang dimiliki Pemerintah Daerah, pendapatan asli Daerah, dana alokasi umum yang di berikan oleh Pemerintah Pusat, dan belanja Daerah yang dilakukan Pemerintah Daerah. Permendagri No. 73/2009 Pasal 5 menyatakan bahwa pengukuran kinerja Pemerintah Daerah berdasarkan LPPD yang telah dibuat oleh Pemerintah Daerah difokuskan pada informasi capaian kinerja pada tataran pengambil kebijakan dan tataran pelaksana kebijakan dengan menggunakan Indikator Kinerja Kunci (IKK), lalu pada Pasal 19 ayat (1) dijelaskan bahwa informasi capaian kinerja pada Aspek tataran pengambil kebijakan terdiri dari 13 Aspek dan 43 IKK.

Penelitian karakteristik Pemeritah Daerah yang dilakukan oleh Sigit (2011) sedikit berbeda dengan penelitian patrick (2007) menurut Sigit (2011) memproksikan karakteristik Pemerintah Daerah berupa ukuran pemerintah daerah, kewajiban, pendapatan transfer, umur pemerintah daerah,dan jumlah SKPD terhadap tingkat pengungkapan wajib di Indonesia. Menurut Sigit (2011) Praktik pengungkapan wajib laporan keuangan pemerintah daerah berdasarkan standar akuntansi pemerintahan di Indonesia masih sangat rendah, dan hal ini menunjukkan bahwa pemerintah daerah belum menyajikan semua informasi yang seharusnya diungkapkan dalam laporan keuangan. Pemerintah daerah belum sepenuhnya memahami informasi apa saja yang wajib diungkapkan dalam laporan keuangan berdasarkan standar akuntansi pemerintahan. Penelitian yang sama dilakukan oleh Siti (2016) menggunakan proksi karakteristik pemerintah daerah berupa ukuran pemerintah daerah, tingkat kekayaan daerah, tingkat ketergantungan pada pemerintah pusat, dan belanja daerah terhadap kinerja pemda. Menurut Siti (2016) semakin besar ukuran pemerintah daerah, dan tingkat kekayaan daerah maka semakin tinggi kinerja yang dimiliki pemerintah daerah, namun tingkat ketergantungan pada pemerintah pusat dan belanja daerah tidak mempengaruhi kinerja pemerintah daerah.

\subsection{Rumusan Masalah}

Berdasarkan permasalahan tersebut, maka dapat dirumuskan pertanyaan penelitian sebagai berikut:

1) Apakah ukuran pemerintah daerah berpengaruh kinerja pemerintah daerah pada Kabupaten/Kota di Provinsi Jambi ?

2) Apakah tingkat kekayaan daerah berpengaruh kinerja pemerintah daerah pada Kabupaten/Kota di Provinsi Jambi?

3) Apakah tingkat ketergantungan pada pusat berpengaruh kinerja pemerintah daerah pada Kabupaten Kota di Provinsi Jambi?

4) Apakah rasio belanja modal berpengaruh kinerja pemerintah daerah pada Kabupaten /Kota di Provinsi Jambi?

5) Apakah ukuran legislatif berpengaruh kinerja pemerintah daerah pada Kabupaten /Kota di Provinsi Jambi?

6) Apakah leverage berpengaruh kinerja pemerintah daerah pada Kabupaten /Kota di Provinsi Jambi?

7) Apakah ukuran pemerintah daerah, tingkat kekayaan daerah, tingkat ketergantungan pada pusat, belanja modal, ukuran legislatif, dan leverage berpengaruh terhadap kinerja pemerintah daerah pada Kabupaten/Kota di Provinsi Jambi? 


\section{TINJAUAN PUSTAKA, KERANGKA PEMIKIRAN DAN HIPOTESIS}

\subsection{Tinjauan Pustaka}

\subsubsection{Karakteristik Pemerintah Daerah}

Menurut Kamus umum Bahasa Indonesia (2006) karakteristik merupakan ciri-ciri khusus; mempunyai sifat khas (kekhususan) sesuai dengan perwatakan tertentu yang membedakan sesuatu (orang) dengan sesuatu yang lain. Pemerintahan Daerah adalah penyelenggaraan urusan pemerintahan oleh Pemerintah Daerah dan Dewan Perwakilan Rakyat Daerah menurut asas otonomi dan tugas pembantuan dengan prinsip otonomi seluas-luasnya dalam sistem dan prinsip Negara Kesatuan Republik Indonesia sebagaimana dimaksud dalam Undang-Undang Dasar Negara Republik Indonesia Tahun 1945.

Penelitian yang dilakukan oleh Hasibuan (2009) terhadap sektor swasta mengukur karakteristik perusahaan terhadap kinerja perusahaan. Hasil dari penelitian ini menemukan bahwa terdapat pengaruh karakteristik perusahaan terhadap kinerja suatu perusahaan. Hal tersebut dapat diterapkan pada sektor pemerintahan, dimana karakteristik daerah dapat menjadi prediktor yang baik dalam mengukur kinerja pemda.

Penelitian mengenai karakteristik pemda telah dilakukan oleh Sumarjo (2010) yang diterapkan pada Pemerintah Daerah Kab/Kota se-Indonesia. Penelitian ini menggunakan Karakteristik Pemerintah Daerah sebagai Variabel Independen meliputi ; Ukuran Pemda, Tingkat Kekayaan Daerah, Ukuran Legislatif, dan Tingkat Ketergantungan. Lalu penelitian oleh Anzarsary (2014) melakukan penelitian yang sama diterapakn pada Pemda Kab/Kota se-Jawa Tengah, dengan variabel karakteristik pemerintah daerah sama seperti Sumarjo (2010).

Penelitian terbaru yang juga dilakukan oleh Harumiati (2014) yang diterapkan pada Pemerintah Daerah Provinsi di Indonesia. Penelitian ini menggunakan Karakteristik Pemerintah Daerah sebagai Variabel Independen meliputi; Ukuran Pemda, Tingkat Kekeyaan daerah, Tingkat Ketergantungan pada Pusat, dan Belanja Modal. Lalu penelitian serupa oleh Siti (2016) diterapkan pada Pemda Kab/Kota se-Indonesia dengan variabel yang sedikit berbeda dengan mengganti variabel belanja daerah dengan belanja daerah. Lain halnya dengan Suharti (2017) mengukur Karakteristik Pemerintah Daerah hanya menggunakan Variabel Independen yaitu Tingkat Kekayaan dan Realisasi Belanja Modal yang diterapkan di Pemerintah Daerah Se-Indonesia.

\subsubsection{Laporan Penyelenggaraan Pemerintah Daerah (LPPD)}

PP No.3/2007 tentang Laporan Penyelenggaraan Pemerintahan Daerah kepada Pemerintah, Laporan Keterangan Pertanggungjawaban Kepala Daerah Kepada Dewan Perwakilan Rakyat Daerah, dan Informasi Laporan Penyelenggaraan Pemerintahan Daerah kepada Masyarakat Pasal 1, LPPD merupakan laporan penyelenggaraan pemerintahan selama satu tahun berdasarkan Rencana Kerja Pembangunan Daerah (RKPD) yang disampaikan oleh Kepala Daerah kepada Pemerintah. Dalam Pasal 9 PP No.3/2007 tersebut juga dijelaskan bahwa sebagai perwujudan adanya transparansi dan akuntabilitas terhadap masyarakat, LPPD dapat dijadikan sebagai salah satu bahan evaluasi kinerja terhadap penyelenggaraan pemerintah daerah. Dengan adanya LPPD diharapkan Pemda mampu menjelaskan kegiatan penyelenggaraan desentralisasi pemerintahan yang meliputi urusan wajib, urusan pilihan, serta tugas pembantuan dan tugas umum pemerintahan sesuai dengan ketentuan peraturan perundang-undangan. Urusan wajib adalah urusan yang sangat mendasar yang berkaitan dengan hak dan pelayanan dasar warga negara. Sedangkan urusan pilihan merupakan urusan yang secara nyata ada di daerah dan berpotensi untuk meningkatkan kesejahteraan masyarakat, sesuai dengan kondisi kekhasan dan potensi unggulan daerah.

\subsubsection{Evaluasi Kinerja Penyelenggaraan Pemerintah Daerah (EKPPD)}

EKPPD merupakan analisis pengumpulan data yang dilakukan terhadap sistem kinerja penyelenggaraan Pemerintah Daerah dengan menggunakan pengukuran kinerja yang dilakukan secara sistematis. Tujuan dilakukannya EKPPD berdasarkan PP No. 6/2008 Pasal 1 adalah untuk menilai kinerja penyelenggaraan pemerintahan daerah dalam upaya peningkatan kinerja berdasarkan prinsip tata kepemerintahan yang baik. Sasaran EKPPD meluputi tataran pengambil kebijakan daerah dan tataran pelaksana kebijakan daerah.

Hasil dari EKPPD yaitu berupa Laporan Hasil Evaluasi Pemeringkatan Kinerja Penyelenggaraan Pemerintah Daerah. Pelaksanaan EKPPD diatur lebih lanjut berdasarkan Surat Edaran yang dikeluarkan oleh Kementerian Dalam Negeri setiap tahunnya tentang Manual Tata Cara EKPPD. Pemeringkatan indeks EKPPD Pemerintah Kabupaten dan Kota se-wilayah Provinsi dan Nasional, serta Pemeringkatan indeks EKPPD Pemerintah Provinsi secara Nasional sesuai yang diatur didalam Manual Tata Cara EKPPD terdiri 
dari 4 kategori prestasi yaitu : (1) Tinggi,(2) Sedang,(3) Cukup,(4) Rendah.

\subsection{Kerangka Pemikiran}

Berdasarkan dari penelitian terdahulu, maka pada penelitian ini dapat disusun kerangka pemikiran terdapat pada gambar model penelitian, sebagai berikut;

\section{Gambar 1.}

Model Penelitian

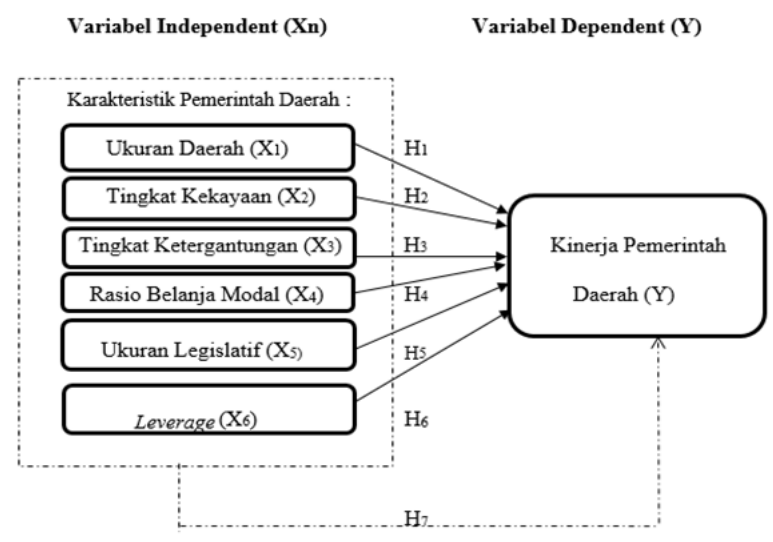

\subsection{Hipotesis}

Penelitian Pengaruh Karakteristik Pemerintah Daerah terhadap Kinerja Pemerintah Daerah Kab/Kota di Provinsi Jambi, terdapat hipotesis yang digunakan, yaitu :

$\mathrm{H}_{1}$ : Ukuran pemda berpangaruh terhadap kinerja pemerintah daerah Kabupaten/Kota di Provinsi Jambi.

$\mathrm{H}_{2}$ : Tingkat kekayaan daerah berpangaruh terhadap kinerja pemerintah daerah Kabupaten/Kota di Provinsi Jambi.

$\mathrm{H}_{3}$ : Tingkat ketergantungan pada pusat berpengaruh terhadap kinerja pemerintah daerah Kabupaten /Kota di Provinsi Jambi.

$\mathrm{H}_{4}$ : Rasio belanja modal berpengaruh terhadap kinerja pemerintah daerah

Kabupaten /Kota di Provinsi Jambi.

$\mathrm{H}_{5}$ : Ukuran legislatif berpengaruh terhadap kinerja pemerintah daerah Kabupaten/Kota di Provinsi Jambi.

$\mathrm{H}_{6}$ : Leverage berpengaruh terhadap kinerja pemerintah daerah Kabupaten/Kota di Provinsi Jambi.

$\mathrm{H}_{7}$ : Ukuran pemerintah daerah, tingkat kekayaan daerah, tingkat ketergantungan pada pusat, belanja modal, ukuran legislatif, dan leverage berpengaruh kinerja pemerintah daerah pada Kabupaten/Kota di Provinsi Jambi?

\section{METODOLOGI PENELITIAN}

\subsection{Populasi dan Sampel}

Populasi penelitian dalam penelitian ini adalah Karakteristik Pemerintah Daerah yang diproksikan melalui Ukuran Pemda, Tingkat Kekayaan Daerah, Tingkat Ketergantungan Pemerintah Pusat, Belanja Modal, Ukuran Legislatif, dan Leverage terhadap Kinerja Pemerintah Daerah Kabupaten/Kota di Provinsi Jambi. Subjek penelitian dalam penelitian ini adalah seluruh Pemerintah Kabupaten/Kota di Provinsi Jambi. Keseluruhan pemerintah Kabupaten/Kota tersebut sebanyak 9 kabupaten dan 2 Kota.

\subsection{Variabel Penelitian}

\begin{tabular}{|c|c|c|}
\hline Variabel & $\begin{array}{c}\text { Defenisi / Konsep } \\
\text { Variabel }\end{array}$ & $\begin{array}{c}\text { Indikator } \\
\text { Pengukuran }\end{array}$ \\
\hline $\begin{array}{l}\text { Ukuran } \\
\text { Pemerinta } \\
\text { h Daerah } \\
\left(\mathrm{X}_{1}\right)\end{array}$ & $\begin{array}{l}\text { Ukuran pemerintah } \\
\text { daerah memerlukan } \\
\text { sumber daya dan } \\
\text { fasilitas yang memadai } \\
\text { untuk memberikan } \\
\text { pelayanan kepada } \\
\text { masyarakat, sehingga } \\
\text { ukuran daerah yang } \\
\text { ditandai dengan } \\
\text { besarnya jumlah asset } \\
\text { Pemda. } \\
\text { (Mustikarini,2012) }\end{array}$ & $\begin{array}{l}\text { Log Total Aset } \\
\text { Pemerintah } \\
\text { Daerah }\end{array}$ \\
\hline $\begin{array}{l}\text { Tingkat } \\
\text { Kekayaan } \\
\text { Daerah } \\
\left(\mathrm{X}_{2}\right)\end{array}$ & $\begin{array}{l}\text { Tingkat Kekayaan } \\
\text { daerah dapat di ukur } \\
\text { dengan menggunakan } \\
\text { PAD dibandingkan } \\
\text { dengan total } \\
\text { pendapatan sebagai } \\
\text { proksi pengukuran } \\
\text { tingkat kekayaan } \\
\text { daerah. (Sumarjo,2010) }\end{array}$ & $\mathrm{TKD}=\frac{\text { PAD }}{\begin{array}{c}\text { Total } \\
\text { Pendapatan }\end{array}}$ \\
\hline $\begin{array}{l}\text { Tingkat } \\
\text { Ketergantu } \\
\text { ngan pada } \\
\text { Pusat } \\
\left(\mathrm{X}_{3}\right)\end{array}$ & $\begin{array}{l}\text { Dana Perimbangan } \\
\text { adalah dana yang } \\
\text { bersumber dari } \\
\text { pendapatan APBN yang } \\
\text { dialokasikan kepada } \\
\text { daerah (otonom) untuk } \\
\text { mendanai kebutuhan } \\
\text { daerah dalam rangka } \\
\text { pelaksanaan } \\
\text { Desentralisasi } \\
\text { (Sumarjo,2010) }\end{array}$ & $\mathrm{TKP}=\frac{\mathrm{DAU}}{\begin{array}{c}\text { Total } \\
\text { Pendapatan }\end{array}}$ \\
\hline
\end{tabular}




\begin{tabular}{|c|c|c|}
\hline $\begin{array}{l}\text { Rasio } \\
\text { Belanja } \\
\text { Modal } \\
\left(\mathrm{X}_{4}\right)\end{array}$ & $\begin{array}{l}\text { Rasio belanja modal } \\
\text { terhadap total belanja } \\
\text { daerah mencerminkan } \\
\text { porsi belanja daerah } \\
\text { yang dibelanjakan } \\
\text { untuk membiayai } \\
\text { belanja modal. Dimana } \\
\text { realisasi belanja modal } \\
\text { akan memiliki } \\
\text { multiplier effect dalam } \\
\text { menggerakkan roda } \\
\text { perekonomian daerah. } \\
\text { (Kementrian Keuangan } \\
\text { Republik Indonesia } \\
\text { melalui Direktorat } \\
\text { Jendral Perimbangan } \\
\text { Keuangan, 2012) }\end{array}$ & $\mathrm{BM}=\frac{\text { Total BM }}{\text { Toral }}$ \\
\hline $\begin{array}{l}\text { Ukuran } \\
\text { Legislatif } \\
\left(\mathrm{X}_{5}\right)\end{array}$ & $\begin{array}{l}\text { Ukuran Legislatif } \\
\text { adalah banyaknya } \\
\text { jumlah anggota } \\
\text { legislatif yang bertugas } \\
\text { mengawasi pemerintah } \\
\text { daerah agar pemerintah } \\
\text { daerah dapat } \\
\text { mengalokasikan } \\
\text { anggaran yang ada } \\
\text { untuk dapat digunakan } \\
\text { dengan baik. } \\
\text { (Wasistiono, 2009). }\end{array}$ & $\begin{array}{c}\text { Jumlah Anggota } \\
\text { DPRD di } \\
\text { Kab/Kota di } \\
\text { Provinsi Jambi }\end{array}$ \\
\hline $\begin{array}{l}\text { Leverage } \\
\left(\mathrm{X}_{6}\right)\end{array}$ & $\begin{array}{l}\text { Leverage adalah suatu } \\
\text { tingkat kemampuan } \\
\text { perusahaan dalam } \\
\text { menggunakan aktiva } \\
\text { dan atau dana yang } \\
\text { mempunyai beban tetap } \\
\text { dalam rangka } \\
\text { mewujudkan tujuan } \\
\text { perusahaan untuk } \\
\text { memaksimisasi } \\
\text { kekayaan suatu } \\
\text { organisasi. } \\
\text { (Sartono,2008) }\end{array}$ & $L e v=\frac{\begin{array}{c}\text { Total } \\
\text { Kewajiban }\end{array}}{\text { Total Asset }}$ \\
\hline $\begin{array}{l}\text { Kinerja } \\
\text { Pemerinta } \\
\text { h Daerah } \\
\text { (Y) }\end{array}$ & $\begin{array}{l}\text { Kinerja } \\
\text { Penyelenggaraan } \\
\text { Pemda adalah capaian } \\
\text { atas penyelenggaraan } \\
\text { urusan pemerintah } \\
\text { daerah yang diukur dari } \\
\text { masukan, proses, } \\
\text { keluaran, hasil, } \\
\text { manfaat, dan/atau } \\
\text { dampak. (PP } \\
\text { No.6.2008). Skor } \\
\text { Kinerja Pemda } \\
\text { merupakan hasil } \\
\text { penilaian dari Evaluasi } \\
\text { Penyelenggaraan } \\
\text { Pemerintah Daerah. }\end{array}$ & $\begin{array}{c}\text { Skor Kinerja } \\
\text { Pemda (EKPPD) } \\
\text { Kab/Kota Prov. } \\
\text { Jambi }\end{array}$ \\
\hline
\end{tabular}

\section{HASIL DAN PEMBAHASAN}

\subsection{Hasil Penelitian}

\subsubsection{Analisis Statistik Deskriptif}

Hasil dari pengujian statistik deskriptif pada penelitian dalam yaitu Pengaruh Karakteristik Pemerintah terhadap Kinerja Pemerintah Darah ( Studi pada Pemerintah Kabupaten/Kota di Provinsi jambi) ini dapat dilihat pada tabel 1 di bawah ini:

Tabel 1.

Analisis Statistik Deskriptif

\begin{tabular}{lccccccc}
\hline \hline & $\mathrm{Y}$ & $\mathrm{X} 1$ & $\mathrm{X} 2$ & $\mathrm{X} 3$ & $\mathrm{X} 4$ & $\mathrm{X} 5$ & $\mathrm{X} 6$ \\
\hline \hline Mean & 2.468300 & 3.277402 & 0.059544 & 0.533896 & 0.282893 & 31.49091 & 0.003642 \\
Med & 2.513600 & 3.300100 & 0.048000 & 0.556000 & 0.270000 & 30.00000 & 0.001400 \\
Max & 3.229500 & 3.562900 & 0.190300 & 0.732900 & 0.424800 & 45.00000 & 0.034900 \\
Mini & 1.520500 & 2.629000 & 0.031700 & 0.055900 & 0.141900 & 20.00000 & 0.000000 \\
StDev & 0.439798 & 0.175935 & 0.030631 & 0.103671 & 0.071275 & 5.862223 & 0.006272 \\
& & & & & & & \\
Obs & 55 & 55 & 55 & 55 & 55 & 55 & 55 \\
\hline
\end{tabular}

Sumber : Data Olah Eview10

Hasil dari Tabel 1 di atas, dapat terlihat bahwa jumlah observasi yang digunakan dalam penelitian ini masing-masing berjumlah 55 data. Nilai minimum merupakan nilai terendah untuk setiap variabel, sedangkan nilai maksimum merupakan nilai tertinggi untuk setaip variabel dalam variabel. Nilai mean merupakan rata-rata dari setiap variabel yang diteliti. Deviasi standar merupakan sebaran data yang digunakan dalam penelitian yang mencerminkan data tersebut heterogen atau homogen yang sifatnya fluktuatif.

Data-data yang diperoleh dari variabel yang diteliti diantaranya Skor Kinerja (Y), nilai minimum sebesar 1.5205, dan nilai maksimum sebesar 3.2295, memiliki nilai rata-rata sebesar 2,4683, dan standar deviasi sebesar 0.439798. Ukuran Pemda (X1) memiliki nilai minimum sebesar 2.6290, nilai maksimum sebesar 3.5629, nilai rata-rata sebesar 3.2274 , dan standar deviasi sebesar 0.175935. Tingkat Kekayaan (X2) memiliki nilai minimum sebesar 0.0317 , nilai maksimum sebesar 0.1903 , nilai rata-rata 0.059544,dan standar deviasi sebesar 0.030631 . Tingkat Ketergantungan pada Pusat (X3) memiliki nilai minimum sebesar 0.7329, nilai maksimum sebesar 0.556000 , nilai rata-rata sebesar 0.533896 , dan standar deviasi sebesar 0.103671. Belanja Modal (X4) memiliki nilai minimum sebesar 0.141900 , nilai maksimum sebesar 0.424800, nilai rata-rata 0.059544,dan standar deviasi sebesar 0.030631. Jumlah Anggota Legislatif (X5) memiliki nilai minimum sebesar 20, nilai maksimum sebesar 45, nilai rata-rata sebesar 31 ,dan standar deviasi sebesar 5.862223. Leverage (X6) 
memiliki nilai minimum sebesar 0.00 , nilai maksimum sebesar 0.034900 , nilai rata-rata 0.003642 , dan standar deviasi sebesar 0.006272 .

\subsubsection{Analisis Regresi Data Panel}

Analisis Regresi Linier Data Panel pada penelitian ini menggunakan metode Fixed Effect. Pemilihan metode Fixed Effects sebagai metode analisis data panel pada penelitian ini sebelumnya diuji melalui uji chow dan uji hausman terlebih dahulu, sehingga akhirnya metode Fixed Effect yang paling tepat untuk menguji data panel pada penelitian ini.

Tabel 2.

Hasil Uji Regresi Data Panel dengan Metode Fixed Effect

\begin{tabular}{crrrr}
\hline Variable & Coefficient & Std. Error & t-Statistic & Prob. \\
\hline \hline C & -0.697730 & 2.239634 & -0.311537 & 0.7571 \\
X1 & 0.259180 & 0.635733 & 0.407688 & 0.6858 \\
X2 & 13.10125 & 4.453332 & 2.941900 & 0.0055 \\
X3 & 1.458748 & 0.663343 & 2.199087 & 0.0340 \\
X4 & 1.181711 & 1.209181 & -0.977282 & 0.3346 \\
X5 & 0.034460 & 0.028776 & 1.197521 & 0.2385 \\
X6 & -1.867381 & 8.924128 & 0.209251 & 0.8354 \\
& & & & \\
\hline \hline
\end{tabular}

Effects Specification

Cross-section fixed (dummy variables)

\begin{tabular}{lclc}
\hline \hline $\begin{array}{l}\text { R-squared } \\
\text { Adjusted }\end{array}$ & 0.610085 & Mean dependent var & 2.468300 \\
$\begin{array}{l}\text { R-squared } \\
\begin{array}{l}\text { S.E. of } \\
\text { regression }\end{array}\end{array}$ & 0.445911 & S.D. dependent var & 0.439798 \\
$\begin{array}{l}\text { Sum } \\
\text { squared }\end{array}$ & 0.327373 & Akaike info criterion & 0.853002 \\
resid & 4.072579 & Schwarz criterion & \\
$\begin{array}{l}\text { Log } \\
\text { likelihood }\end{array}$ & -6.457562 & Hannan-Quinn criter. & 1.473451 \\
$\begin{array}{l}\text { F-statistic } \\
\text { Prob(F- }\end{array}$ & 3.716077 & Durbin-Watson stat & 2.000316 \\
statistic) & 0.000445 & & \\
\hline \hline
\end{tabular}

Persamaan regresi dari data panel pada penelitian, sebagai berikut :

$Y=-0.697730+0.25918 X 1+1.31012 X 2+1.458748$

X3 +1.181711X4 + 0.034460X5 - 1.867381X6

$+\mathbf{0}$

\subsection{Pembahasan}

Hasil dari uji $t$ masing-masing variabel independen terhadap variabel dependen, yaitu :

\subsubsection{Ukuran Pemda tidak berpengaruh terhadap Kinerja Pemda}

Hipotesis pertama yang diajukan pada penelitian ini adalah ukuran Pemda berpangaruh terhadap kinerja
Pemerintah Daerah Kabupaten /Kota di Provinsi Jambi. Berdasarkan hasil uji t yakni hasil pengujian parsial antara variabel ukuran Pemda dengan skor kinerja Pemda menunjukan nilai probabilitas lebih dari 0.05 , dimana nilai probabilitasnya sebesar 0.6858 lebih dari 0.05. Hasil dari penelitian menunjukan bahwa ukuran Pemda tidak berpangaruh terhadap kinerja Pemerintah Daerah Kabupaten /Kota di Provinsi Jambi, hal itu disebabkan ukuran Pemda yang diproksikan dari aset yang dimiliki Pemda Maka dapat disimpulkan bahwa kurang optimalnya Pemda mengelola maupun memanfaatkan aset yang dimiliki sebagai sarana penunjang pencapaian kinerja, seharusnya dengan aset yang besar Pemda dituntut agar mengelola dan mamanfaatkan aset dengan baik, dan aset berperan dalam meningkatkan kinerja di lingkungan Pemda,namun dari hasil penelitian ini tinggi rendahnya ukuran Pemda tidak mempengaruhi skor kinerja yang didapatkan Pemda melalaui hasil EKPPD. Menurut Mardiasmo (2010) menyatakan aset daerah digunakan untuk operasi Pemerintah Daerah, dan juga aset daerah dapat digunakan masyarakat dalam rangka pelayanan publik.

\subsubsection{Tingkat Kekayaan Daerah berpengaruh terhadap Kinerja Pemda}

Hipotesis kedua yang diajukan pada penelitian tingkat kekayaan Daerah berpangaruh terhadap kinerja Pemerintah Daerah Kabupaten /Kota di Provinsi Jambi. Berdasarkan hasil uji t yakni hasil pengujian parsial antara variabel Tingkat Kekayaan Daerah dengan Skor Kinerja Pemda menunjukan nilai probabilitas kecil dari 0.05 , dimana nilai probabilitasnya sebesar 0.0055 lebih kecil dari 0.05. Hasil dari penelitian ini menunjukan bahwa tingkat kekayaan Daerah berpangaruh terhadap kinerja Pemerintah Daerah Kabupaten /Kota di Provinsi Jambi, hal itu disebabkan tingkat kekayaan Daerah yang diproksikan dari perbandingan antara Pendapatan Asli Daerah (PAD) dengan total pendapatan Pemda. Maka dapat disimpulkan bahwa Pemda kinerja Pemda baik dapat tercermin dalam pengelolaan PAD yang baik, pemda mampu memanfaatkan PAD sebagai sarana dalam pencapaian kinerja yang lebih baik, PAD yang dimiliki Pemda dapat menjadi tolak ukur tingkat keberhasilan maupun kekayaan yang dimiliki Pemda dalam pencapaian kinerja setiap tahunnya. Menurut Undang-Undang Nomor 33 Tahun 2004 tentang Dana Perimbangan menyatakan Pendapatan Asli Daerah (PAD) ialah sebagai sarana pendapatan daerah yang bersumber dari hasil pajak daerah, hasil retribusi daerah, hasil pengelolaan kekayaan daerah yang dipisahkan, maupun pendapatan asli daerah lainnya yang sah dengan tujuan memberikan wewenang kepada daerah dalam menggali dan pelaksanaan pendanaan sesuai dengan otonomi daerah sebagai asas desentralisasi. 


\subsubsection{Tingkat Ketergantungan pada Pusat berpengaruh terhadap Kinerja Pemda}

Hipotesis ketiga yang diajukan pada penelitian tingkat ketergantungan pada pusat berpangaruh terhadap kinerja Pemerintah Daerah Kabupaten /Kota di Provinsi Jambi. Berdasarkan hasil uji t yakni hasil pengujian parsial antara variabel ketergantungan pada pusat dengan skor kinerja Pemda menunjukan nilai probabilitas kecil dari 0.05 , dimana nilai probabilitasnya sebesar 0.0340 lebih kecil dari 0.05 . Hasil dari penelitian ini menunjukan bahwa tingkat ketergantungan pada pusat berpangaruh terhadap kinerja Pemerintah Daerah Kabupaten /Kota di Provinsi Jambi, hal itu disebabkan tingkat ketergantungan pada Pusat yang diproksikan dari dapat perbandingan Dana Alokasi Umum (DAU) dengan Total Pendapatan yang dimiliki Pemda dapat dilihat dari Tabel 4.8 pada tingkat ketergantungan pada pusat yang dibandingkan dengan kinerja Pemda hasilnya ialah semua Pemda mengalami peningkatan DAU yang diberikan oleh Pemerintah Pusat setiap tahunnya sebagai pengoptimalisasi maupun pemanfaatan DAU sebagai penunjang pencapaian kinerja lebih baik maupun perwujudan efektifitas dan efisiensi anggran. Lalu terjadinya kestabilan pemberian DAU kepada Pemda dengan tujuan pemeratataan kemampuan keuangan antar Daerah untuk mendanai kebutuhan Daerah dalam rangka pelaksanaan desentralisasi, dan proporsi DAU untuk daerah Kabupaten/Kota ditetapkan sesuai dengan imbangan kewenangan antara Provinsi dan Kabupaten/Kota sesuai dengan prioritas dan kebutuhan daerah untuk peningkagtan pelayanan kepada masyarakat dalam rangka pelaksanaan otonomi daerah menurut Undang-undang Nomor 33 Tahun 2004 tentang Perimbangan Keuangan antara Pemerintah Pusat dan Pemerintah Daerah.

\subsubsection{Rasio Rasio Belanja Modal tidak berpengaruh terhadap Kinerja Pemerintah Daerah}

Hipotesis keempat yang diajukan pada penelitian ini adalah rasio belanja modal berpangaruh terhadap kinerja Pemerintah Daerah Kabupaten /Kota di Provinsi Jambi. Berdasarkan hasil uji t yakni hasil pengujian parsial antara variabel rasio belanja modal dengan skor kinerja Pemda menunjukan nilai probabilitas lebih besar dari 0.05 , dimana nilai probabilitasnya sebesar 0.3346 lebih besar dari 0.05 . Maka dari penelitian ini disimpulkan bahwa rasio belanja modal tidak berpengaruh terhadap kinerja Pemerintah Daerah Kabupaten /Kota di Provinsi Jambi, rasio belanja modal yang diproksikan dari perbandingan antara belanja modal dengan total pendapatan Pemda. Maka dapat disimpulkan bahwa kurangnya pemanfaatan belanja modal sebagai sarana penunjang pencapaian kinerja pemda, lalu masih banyak daerah yang memerlukan pembangunan infrastruktur yang digunakan masyarakat sesuai dengan PP Nomor 71 Tahun 2010 menyatakan bahwa belanja modal yang dimiliki Pemda untuk memperoleh aset tetap seperti peralatan, infrastruktur, dan harta tetap lainnya,melalui melalui proses lelang/tender. Tingkat efisiensi yang sulit diukur dalam pemanfaatan belanja modal sebagai sarana prasarana peningkatan kesejahteraan masyarakat sebagai pengguna barang milik Negara berupa infrastruktur.

\subsubsection{Ukuran Legislatif tidak berpengaruh terhadap Kinerja Pemerintah Daerah}

Hipotesis kelima yang diajukan pada penelitian ini adalah ukuran legislatif berpangaruh terhadap kinerja Pemerintah Daerah Kabupaten /Kota di Provinsi Jambi. Berdasarkan hasil uji t yakni hasil pengujian parsial antara variabel ukuran legislatif dengan skor kinerja Pemda menunjukan nilai probabilitas lebih besar dari 0.05 , dimana nilai probabilitasnya sebesar 0.2385 lebih besar dari 0.05 . Maka dari penelitian ini disimpulkan bahwa ukuran legislatif tidak berpengaruh terhadap kinerja Pemerintah Daerah Kabupaten /Kota di Provinsi Jambi, banyaknya anggota legislatif belum tentu dapat menjadi sumber controlling dalam suatu pemda lebih baik dalam pencapaian kinerja. Penelitan ini sejalan dengan penelitian Sumarjo (2010) yang menyatakan bahwa tidak terdapat pengaruh antara jumlah anggota DPRD terhadap kinerja keuangan daerah di Indonesia.

\subsubsection{Leverage tidak berpengaruh terhadap Kinerja Pemerintah Daerah}

Hipotesis keenam yang diajukan pada penelitian ini adalah leverage berpangaruh terhadap kinerja Pemerintah Daerah Kabupaten /Kota di Provinsi Jambi. Berdasarkan hasil uji t yakni hasil pengujian parsial antara variable leverage dengan skor kinerja Pemda menunjukan nilai probabilitas lebih besar dari 0.05, dimana nilai probabilitasnya sebesar 0.8354 lebih besar dari 0.05. Sehingga dapat disimpulkan bahwa hipotesis keenam yang diajukan pada penelitian ini adalah leverage tidak berpengaruh terhadap kinerja Pemerintah Daerah Kabupaten/Kota di Provinsi Jambi. Hasil dari penelitian ini ialah besarnya Leverage yang dapat dilihat dari perbandingan antara dengan total kewajiban dengan total aset yang dimiliki Pemda, leverage yang dimiliki Pemda tidak dapat menunjang dalam pencapaian kinerja, dikarenkan hutang yang dimiliki pemda dapat menjadi salah satu faktor tingkat pengelolaan anggaran daerah yang tidak efektif, sehingga pemda tidak kekurangan dana dalam pencapaian kegiatan program yang dijalankan dalam satu tahun anggaran. 


\section{SIMPULAN DAN SARAN}

\subsection{Simpulan}

Berdasarkan hasil penelitian dan pembahasan, dapat disimpulkan bahwa pengaruh karakteristik pemerintah daerah terhadap kinerja pemerintah daerah (studi pada pemerintah Kabupaten/Kota di Provinsi Jambi) dapat dijelaskan bahwa :

1. Ukuran Pemda tidak berpengaruh terhadap kinerja Pemda Kabupaten/Kota di Provinsi Jambi, H1 tidak terbukti dikarenakan nilai probabilitas pada Ukuran Pemda sebesar $0.6858>0.05$, sehingga hipotesis 1 (H1) yang menyatakan ukuran Pemda berpengaruh terhadap kinerja Pemda tidak terbukti atau ditolak. Besarnya ukuran pemda yang dapat dilihat dari besarnya asset yang dimiliki seharusnya dapat menunjang kinerja pemda yang lebih baik, dan pemanfaatan asset pemda sebagai penunjang pencapaian kinerja yang lebih baik dari sebelumnya.

2. Tingkat kekayaan Daerah berpengaruh terhadap kinerja Pemda Kabupaten/Kota di Provinsi Jambi, $\mathrm{H} 2$ terbukti dikarenakan nilai probabilitas pada tingkat kekayaan daerah sebesar sebesar $0.0055<0$ .05 , sehingga hipotesis 2 (H2) yang menyatakan tingkat kekayaan Daerah berpengaruh terhadap kinerja Pemda terbukti atau diterima. Besarnya tingkat kekayaan daerah yang dapat dilihat dari perbandingan Pendapatan Asli Daerah (PAD) dengan total pendapatan yang dimiliki Pemda dapat menjadi faktor dalam penilaian kinerja pemda, dan pada pencapaian kinerja tingkat kekayaan daerah menjadi penunjang dalam skor kinerja yang didapatkan Pemda.

3. Ketergantungan pada pusat berpengaruh terhadap kinerja Pemda Kabupaten/Kota di Provinsi Jambi, H3 terbukti dikarenakan nilai probabilitas pada Ketergantungan pada Pusat sebesar $0.0340<0.05$, sehingga hipotesis $3(\mathrm{H} 3)$ terbukti atau diterima. Besarnya ketergantungan pada pusat yang dapat dilihat dari perbandingan Dana Alokasi Umum (DAU) dengan total pendapatan yang dimiliki Pemda, Pemda memanfaatkan Dana Alokasi Umum (DAU) yang dimiliki sebagai penunjang pencapaian kinerja Pemda.

4. Belanja modal tidak berpengaruh terhadap kinerja Pemda Kabupaten/Kota di Provinsi Jambi, H4 tidak terbukti dikarenakan nilai probabilitas pada Belanja Modal sebesar $0.3346>0.05$, sehingga hipotesis 4 (H4) tidak terbukti atau ditolak. Belanja modal belum dimanfaatkan secara penuh dalam pencapaian kinerja pemda,dan besar kecil nya belanja modal yang dimiliki pemda dalam pengelolaan belanja modal sebagai sumber daya dalam pencapaian kinerja semua tergantung bagaimana cara pemda mengelola belanja modal tersebut menjadi sarana prasarana dalam penilaian sumber daya untuk pencapaian kinerja.

5. Anggota legislatif tidak berpengaruh terhadap Kinerja Pemda Kabupaten/Kota di Provinsi Jambi, H5 tidak terbukti dikarenakan nilai probabilitas pada Anggota legislatif sebesar $0.2385>0.05$, sehingga hipotesis 5 (H5) tidak terbukti atau ditolak. Banyaknya anggota legislatif belum tentu dapat menjadi sumber controlling dalam suatu pemda lebih baik dalam pencapaian kinerja.

6. Leverage tidak berpengaruh terhadap Kinerja Pemda Kabupataen/Kota di Provinsi Jambi. H6 tidak terbukti dikarenakan nilai probabilitas pada Leverage sebesar $0.8354>0.05$, sehingga hipotesis 6 (H6) tidak terbukti atau ditolak. Tingginya skor kinerja Pemda yang dimiliki tidak mempengaruhi besar atau kecilnya Leverage yang dimiliki pemda, setiap Pemda memiliki pembiayaan berbeda-beda sesuai dengan kebutuhan maupun populasi yang terdapat di wilayah Pemda tersebut.

7. Secara simultan Ukuran Pemda, Tingkat Kekayaan Daerah, Ketergantungan pada Pusat, Belanja Modal, Ukuran Legislatif, dan Leverage berpengaruh terhadap Kinerja Pemda pada Kabupaten/Kota Provinsi Jambi. H7 terbukti dikarenakan nilai hal ini dapat dilihat nilai dari Prob (F-statistic) sebesar $0.000445<0.05$, maka hipotesis 5 (H5) terbukti atau diterima. Selanjutnya Ukuran Pemda, Tingkat Kekayaan Daerah, Ketergantungan Pada Pusat, Belanja Modal, Anggota Legislatif, dan Leverage tersebut mampu menjelaskan oleh nilai determinasi mencapai $44.59 \%$.

\subsection{Saran}

Sehubungan dengan hasil simpulan yang telah diperoleh dalam penelitian ini, maka peneliti mengemukakan saran yaitu :

1. Pemerintah daerah kabupaten/kota khususnya di Provinsi Jambi agar dapat meningkatkan kinerja dari hasil Evaluasi Kinerja Penyelenggaraan Pemerintahan Daerah (EKPPD), dikarenakan masih banyak tingkat skor berskala sedang. Lalu dari jangka periode terjadinya naik dan turunnya skor kinerja. Hasil dari EKPPD bertujuan berdasarkan PP No. 6/2008 Pasal 1 adalah untuk menilai kinerja penyelenggaraan pemerintahan daerah dalam upaya peningkatan kinerja berdasarkan prinsip tata kepemerintahan yang baik.

2. Bagi peneliti selanjutnya yang akan melakukan penelitian yang sama, dapat mempertimbangkan hal-hal berikut:

a. Menambahkan variabel independen dalam model penelitian, misalnya belanja daerah, temuan audit, status daerah,dan jumlah SKPD. 
b. Memperluas area penelitian bisa saja mencakup seluruh Indonesia atau membandingkan antara Pulau bahkan Provinsi.

c. Memperpanjang periode penelitian lebih dari 5 tahun, agar dapat mencerminkan kondisi kabupaten dan kota dalam jangka panjang.

\section{DAFTAR REFERENSI}

Abdullah, S. \& Abdul, H. 2006. Studi atas Belanja Modal pada Anggaran Pemerintah Daerah dalam Hubungannya dengan Belanja Pemeliharaan dan Sumber Pendapatan. Jurnal Akuntansi Pemerintah,

Volume 2 No. 2, November.

Agus, Dwiyanto. 2005. Mewujudkan Good Governance melalui Pelayanan Publik. Yogyakarta : Gadjah Mada University Press.

Ayu,Rahayu. 2016. Pengaruh karakteristik, kompleksitas, dan temuan audit terhadap tingkat pengungkapan laporan keuangan pemerintah daerah dengan sistem pengendalian intern sebagai variabel moderating pada LKPD kabupaten/kota di sulawesi selatan. Jurnal Ilmiah Akuntansi Peradaban : Dosen Akuntansi UIN Alauddin Makasar.

Bastian, I. 2006. Akuntansi Sektor Publik di Indonesia, Edisi pertama, BPFE, UGM, Yogyakarta.

Basuki, A. \& Tri, P. 2016. Analisis Regresi Dalam Penelitian Ekonomi dan Bisnis, Depok : PT. Rajagrafindo Persada.

Elmi, Bachrul. 2002. Kebijakan Desentralisasi Fiskal Kaitannya dengan Hutang Luar Negeri Pemerintah Daerah Otonom. Kajian Ekonomi dan Keuangan. Vol. 6 (4).

Ghozali, I. 2011. Aplikasi Analisis Multivariate Dengan Program SPSS 19. Semarang: Badan Penerbit Universitas Diponegoro.

Halim, A. 2004. Akuntansi Keuangan Daerah. Jakarta : Salemba Empat.

Halim, A. 2014. Manajemen Keuangan Daerah. Semarang: Bunga Rampai, Yogyakarta : UPP AMP YKPN (Edisi Ketiga).

Hartono,dkk. 2014. Faktor- Faktor Yang Mempengaruhi Kelemahan Pengendalian Intern Pemerintah Daerah". SNA 17 Mataram. Lombok: Universitas Mataram.

Harumiati,Y. \& Payamta. 2014. Pengaruh Karakteristik Pemerintah Daerah dan Temuan Audit BPK terhadap Kinerja Pemerintah Daerah Kabupaten/Kota di Indonesia Tahun Anggaran 2011. Surakarta : Magister Akuntansi Universitas Sebelas Maret Surakarta.

Hasibuan, M. 2009. Manajemen Dasar Edisi Revisi. Jakarta : Bumi Aksara.

Kusumawardani. 2012. Pengaruh Size, Kemakmuran, Ukuran Legislatif, Levarge terhadap Kinerja Keuangan Pemda di Indonesia. Semarang: UNNES.

Krisna, Putu. 2008. Pengaruh Lingkungan Kerja, Stres dan Konflik Kerja terhadap Kinerja Karyawan di PT. Bank Sri Partha Kantor Pusat Denpasar. Tesis Magister Manajemen. Denpasar: Universitas Udayana Denpasar.

Lembaga Administrasi Negara RI. 2005. Acuan Umum Penerapan Good Governance Pada Sektor Publik. Jakarta.

Lesmana, S. I. 2010. Pengaruh Karakteristik Pemda Terhadap Tingkat Pengungkapan Wajib di Indonesia". Thesis. Surakarta: Fakultas Ekonomi Universitas Sebelas Maret.

Mahsun, Mohamad. 2014. Pengukuran Kinerja Sektor Publik. Yogyakarta : BPFE.

Mardiasmo. 2010. Akuntansi Sektor Publik. Yogyakarta: Penerbit Andi.

Mardiasmo. 2002. Otonomi dan Manajemen Keuangan Daerah. Yogyakarta : BPFE.

Mustikarini,W. \& Fitriasasi, D. 2012. Pengaruh Karakteristik Pemerintah Daerah dan Temuan Audit Bpk Terhadap Kinerja Pemerintah Daerah Kabupaten/Kota di Indonesia Tahun Anggaran 2007. Forum: Simposium Nasional Akuntansi 15, http//www.sna.akuntansi.unikal.ac.id

Pratiwi, R. \& Aryani. 2016. Pengaruh Karakteristik Pemerintah Daerah, Kepala Daerah, Tindak Lanjut Temuan Audit terhadap Opini. Surakarta : Magister Akuntansi Universitas Sebelas Maret Surakarta.

Priyatno, D. 2014. SPSS 22 Pengolah Data Terpraktisi, Andi, Yogyakarta.

Patrick, PA 2007. The Determinant of Organizational Inovativeness: The Adoption of GASB 34 in Pennsylvania Local Government. Unpublished Ph.D. Dissertation . Pennsylvania: The Pennsylvania State University. Jhinga, ML. 2000. Economic Planning and Development. 
Peraturan Direktorat Jendral Perbendaharaan Nomor 37 Tahun 2014, Jakarta : Direktorat Jendral Perbendaharaan.

Peraturan Menteri Dalam Negeri Nomor 73 Tahun 2009 tentang Tatacara Pelaksanaan Evaluasi Penyelenggaraan Pemerintahan Daerah. Jakarta : Kementrian Dalam Negeri.

Peraturan Pemerintah Nomor 13 Tahun 2006 tentang Pedoman Pengelolaan dan Pelaksana Keuangan Daerah, Jakarta : Kementrian Dalam Negeri.

Peraturan Pemerintah Nomor 6 Tahun 2008 tentang Pedoman Evaluasi Penyelenggaraan Pemerintah Daerah. Jakarta : Kementrian Dalam Negeri.

Peraturan Pemerintah Nomor 8 Tahun 2006 tentang Pelaporan Keuangan dan Kinerja Instansi Pemerintah. Jakarta : Kementrian Dalam Negeri.

Peraturan Pemerintah Nomor 3 Tahun 2007 tentang Laporan Penyelenggaraan Pemerintah Daerah, Jakarta : Kementrian Dalam Negeri.

Peraturan Pemerintah Nomor 30 Tahun 2011 tentang Pinjaman Daerah, Jakarta : Kementrian Dalam Negeri.

Peraturan Pemerintah Nomor 58 Tahun 2005 tentang Pengelolaan Keuangan Daerah, Jakarta : Kementrian Dalam Negeri.

Peraturan Pemerintah Nomor 71 Tahun 2010 tentang Standar Akuntansi Pemerintah. Jakarta : Kementrian Dalam Negeri.

PMK Nomor 201/PMK.07/2012 tentang Pedoman Umum dan Alokasi Dana. Jakarta : Kementrian Keuangan.

Petrick.A.P. 2007. The Determinants Of Organizational Innovativeness:

The Adoption Of Gasb 34 In Pennsylvania Local Government. Pennsylvania : The Pennsylvania State University.

Priyatno, D. 2014. SPSS 22 Pengolah Data Terpraktisi, Andi, Yogyakarta.

Rini, Rossa. 2015. Pengaruh Aspek Tataran Pengambil Kebijakan Terhadap Kinerja Penyelenggaraan Pemerintah Daerah Kabupaten Dan Kota Di Sumatera Tahun 2010-2012. Jambi: Magister Ilmu Akuntansi Universitas Jambi.

Sartono, R. 2008. Manajemen Keuangan ( Teori dan Aplikasi).Yogyajarta : BPFE.

Sekaran, U. 2009. Research Methods for Business : Metodologi Penelitian untuk Bisnis. Edisi 4. Jakarta : Salemba Empat.
Siti, Juwenty. 2016. Pengaruh Karakteristik Pemerintah Daerah dan Temuan Audit BPK terhadap Kinerja Pemerintah Daerah Provinsi di Indonesia. Bandar Lampung : Magister Ilmu Akuntansi Universitas Lampung.

Sudarsana. \& Rahardjo. 2013. Pengaruh Karakteristik Pemeritah Daerah dan Temuan Audit BPK terhadap Kinerja Pemerintah Daerah (Studi pada Pemerintah Kabupaten/Kota di Indonesia).Journal Of Accounting Volume 2, Nomor 4 Tahun 2013.

Suhardjanto, D. \& Yulianingtyas, R.R. 2011. Pengaruh Karakteristik Pemerintah Daerah Terhadap Kepatuhan Pengungkapan Wajib Dalam Laporan Keuangan Pemerintah Daerah (Studi Empiris pada Kabupaten/Kota di Indonesia)". Jurnal Akuntansi \& Auditing, Volume 8/No. 1/November 2011.

Suharti, E. 2017. Pengaruh Temuan Audit, Pengungkapan Informasi Keuangan di Website dan Karakteristik Pemetintah Daerah terhadap Kinerja Penyelenggaraan Pemerintah Daerah di Indonesia. Bandar Lampung: Magister Ilmu Akuntansi Universitas Lampung.

Syakhroza, A. 2007. Governance for (Public Expenditure Management). Universitas Indonesia.

Undang-Undangan Nomor 7 Tahun 2017 tentang Pemilu Anggota Legislatif.

Undang-Undangan Nomor 17 Tahun 2014 tentang $M P R, D P R, D P D, D P R D$.

Undang-Undangan Nomor 23 Tahun 2014 tentang Pemerintah Daerah.

Undang-Undangan Nomor 32 Tahun 2004 tentang Pemerintah Daerah.

Undang-Undangan Nomor 33 Tahun 2004 tentang Dana Perimbangan.

Undang-Undangan Nomor 17 Tahun 2003 tentang Keuangan Negara.

Undang-Undangan Dasar 1945 Pasal 18 (amandemen II Tahun 2002) tentang Otonomi Daerah.

Ulum, I. 2009. Audit Sektor Publik Suatu Pengantar. Jakarta : Bumi Aksara.

Wasistiono, S. 2009. Meningkatan Kinerja Dewan Perwakilan Rakyat Daerah (DPRD). Bandung : Alqa Print.

2006. Kamus Bahasa Indonesia Edisi 3. Jakarta: Balai Pustaka.

www.djpk.depkeu.go.id. 
www.jambiprov.go.id

www.kpu.go.id

www.jariungu.com

www.tanjabtimkab.go.id

www.otda.kemendagri.go.id. 